Proceedings of the Institution of
Civil Engineers
Structures \& Buildings 159
April 2006 Issue SB2
Pages 103-1/4
Paper 14028
Received 16/1 I/2004
Accepted 05/I0/2005
Keywords:
beams/failures/timber structures
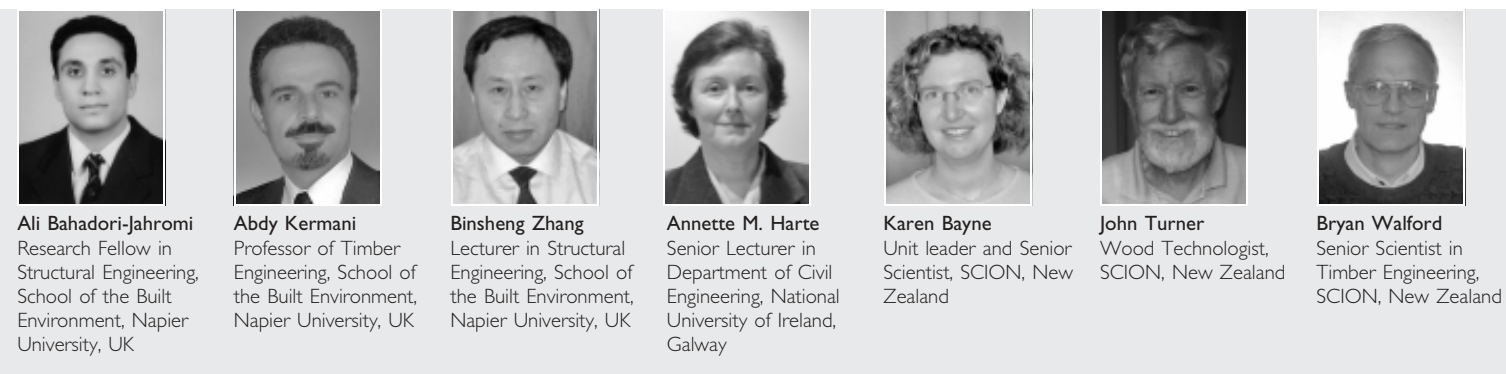

\title{
Influence of cross-section on the strength of timber beams
}

A. Bahadori-Jahromi MSc, PhD, A. Kermani MSc, PhD, CEng, MIStructE, FIWSc, B. Zhang MSc, PhD, A. M. Harte MEng, PhD, CEng, MIEl, K. Bayne BTech, J. Turner MSc and B. Walford MSc, PhD

This paper investigates the strength and deformation characteristics of lightweight timber composite beams manufactured with six different cross-sectional profiles in comparison with readily available laminated veneer lumber (LVL) and glued-laminated (Glulam) beams. All engineered profiles comprised solid timber or LVL flanges and three-ply plywood webs. The number of webs varied from one to four. The beams had an overall depth of $290 \mathrm{~mm}$ and were either $88 \mathrm{~mm}$ or $106 \mathrm{~mm}$ wide. A study was conducted to provide a comparison of the beam designs and to determine possible effects of cross-sectional configuration and connection details on the structural properties of the beams. To enable a realistic analysis, 12 beams were replicated for each design. The individual components of the beams were tested prior to assembly to obtain the modulus of elasticity and shear modulus and were grouped to provide an even distribution of the material properties. The addition of extra webs to the I-beam profile significantly enhanced the bending and shear capacity of the beam while maintaining a high strength to weight ratio. The boxed I-beam proved to be the most efficient to manufacture and displayed superior structural performance compared with the rest of the profiles in terms of flexural stiffness and bending and shear capacity. The experimental results confirmed the significant contribution of the shear deflection to the total deflection of the I-beams, box beams and even solid section beams.

\section{INTRODUCTION}

Engineered timber structural members are products constructed from a combination of timber in its various forms (usually in small sections free from defects) or wood-based products using adhesives or other types of connections such as nails, screws or staples. They are generally stronger, stiffer and more stable than solid sawn timber. The growing use of engineered timber structural components for timber-framed construction is increasing the need for more efficient geometrical properties, longer spans, reduced shrinkage, defect-free characteristics and economical solutions.

Beam members are predominantly subjected to bending, coexisting with shear, bearing and buckling. Besides having sufficient strength capabilities to resist these effects, it is important that the beams have adequate stiffness to avoid excessive deflection or local buckling of the cross-section. Traditionally, only the deflection component of a beam owing to bending is considered since the shear modulus for materials such as steel, is considerably higher as a percentage of the true elastic modulus than in timber. The shear deformation is, however, a significant proportion of the overall deflection of a timber beam or an engineered timber beam. A number of factors, such as the geometrical configuration, the shear modulus of the web materials and the loading type and position, influence the shear deformation of a beam.

This paper presents part of a comprehensive study of the structural performance for a range of engineered composite timber beams with regard to strength and deformation characteristics. The beams comprise six different crosssectional profiles, adhesively bonded together, in addition to commercially available solid laminated veneer lumber (LVL) and glued-laminated (Glulam) timber beams, as shown in Fig. 1. In order to provide a standard basis for comparison, no stiffeners or splice pieces were used. The influences of geometrical (cross-sectional) configurations on the shear characteristics of the engineered composite timber beams were investigated and their influence on the strength and stiffness properties of the beams was determined and compared.

\section{MANUFACTURE OF ENGINEERED BEAMS}

\section{I. Geometric properties of the beams}

In this study, nine types of composite beams with six different cross-sectional profiles were manufactured and two types of solid section, LVL and Glulam beams, were obtained from the market (Fig. 1). All timber, plywood, LVL and Glulam products used in this study were produced from New Zealand Radiata pine.

The composite beams had solid timber or LVL flanges $88 \mathrm{~mm}$ wide and $45 \mathrm{~mm}$ deep and had overall dimensions of 88 (106) $\times 290 \mathrm{~mm}$. A $9 \mathrm{~mm}$ thick three-ply plywood of stress grade F $11^{1}$ was used for the webs of all composite beams. The solid timber flanges were cut from sections of New Zealand Radiata pine of grade $\mathrm{F}^{2}$ and used in profiles 1a, 2a, 3, 4, 5a and 6 . The LVL sections were used for flanges of profiles $1 \mathrm{~b}, 2 \mathrm{~b}$ and $5 \mathrm{~b}$. Each profile was produced in two lengths: $2.3 \mathrm{~m}$ (short beams) and $4 \cdot 8 \mathrm{~m}$ (long beams) for effective spans of $2 \cdot 1 \mathrm{~m}$ and 


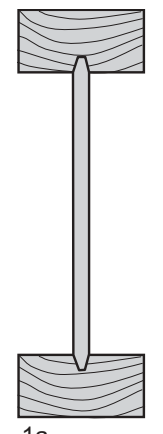

$1 a$

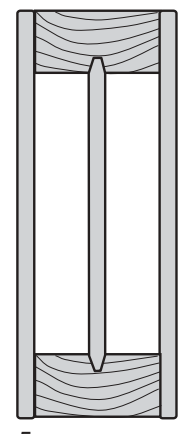

5 a
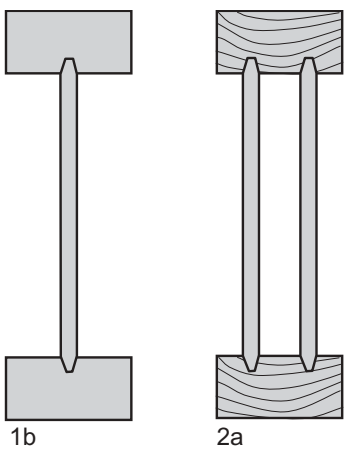

$2 a$

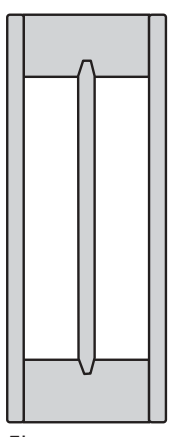

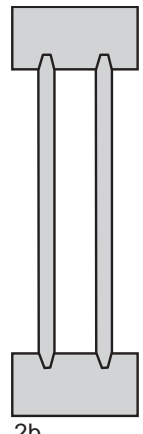

$2 b$

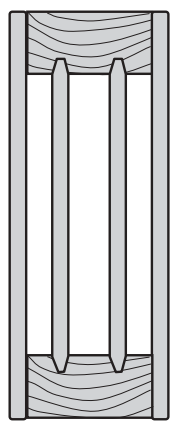

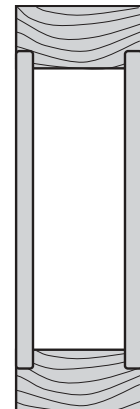

3

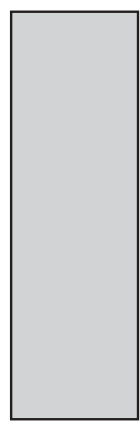

7

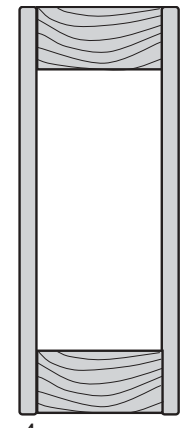

4

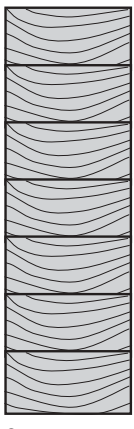

8

Beams with timber flanges:
(1a) I-beam;
(2a) Double I-beam;
(3) Recessed beam
(4) Box beam; (5a) Boxed I-beam;
(6) Boxed double I-beam.

Beams with LVL flanges:

(1b) I-beam; (2b) Double I-beam; (5b) Boxed double I-beam.

Solid section beams:

(7) LVL beam; (8) Glulam beam.

4.35 m respectively. The short beams were replicated 12 times and the long beams three times. A structural adhesive for timber with a liquid hardener, a resorcinol formaldehyde from family of phenolic resin, ${ }^{3}$ was used for bonding the webs to the flanges. Ready-made LVL and Glulam beams were obtained from local manufacturers in New Zealand. Profiles 1a, 1b, 2a, $2 \mathrm{~b}$ and 3 had overall dimensions of $88 \times 290 \mathrm{~mm}$ and profiles 4, 5a, 5b and 6 had overall dimensions of $106 \times 290 \mathrm{~mm}$. The solid LVL and Glulam beams were $88 \times 290 \mathrm{~mm}$.

\subsection{Material properties}

Prior to manufacturing and cutting the sections to the desired sizes, a series of tests was carried out to determine the modulus of elasticity, shear modulus, density and moisture content of the timber, plywood and LVL. The modulus of elasticity of the timber and LVL flanges were measured in accordance with AS/ NZS $4063^{4}$ for both the short and long beams. Flanges were tested under four-point bending.

In order to make a realistic assessment and comparison of the performance of the beams with different geometrical configurations, it was necessary to group the components to provide an even distribution of the material properties and match them accordingly. This would allow each set of specimens to comprise a similar range of components in respect of the material properties.

The modulus of elasticity of the timber varied from $5 \cdot 4$ to $16.7 \mathrm{kN} / \mathrm{mm}^{2}$ with a mean value of $9.5 \mathrm{kN} / \mathrm{mm}^{2}$, while more consistent results were obtained for LVL, ranging from $10 \cdot 2$ to $12.9 \mathrm{kN} / \mathrm{mm}^{2}$ with a mean value of $11.5 \mathrm{kN} / \mathrm{mm}^{2}$. The mean densities of the oven-dried timber, LVL and plywood were 437, 496 and $456 \mathrm{~kg} / \mathrm{m}^{3}$, respectively (Table 1 ).

The whole programme lasted four months, from manufacturing to testing. During this time the mean moisture content for LVL changed from $15 \cdot 15 \%$ at manufacturing to an equilibrium value of $11.70 \%$ during testing. The moisture content of the timber section, however, remained little changed from 12.06 to $12 \cdot 55 \%$.

For plywood, six specimens were randomly selected out of 140 plywood sheets and tested for the modulus of elasticity, modulus of rigidity, moisture content and density. The full results are summarised in Table 1 . The second moment of area and the section modulus of plywood were determined according to the recommendations of AS/NZS 2269. ${ }^{1}$ Using a transformed section method to account for the difference in ply 


\begin{tabular}{|c|c|c|c|c|c|c|}
\hline Parameters & Unit & $\begin{array}{l}\text { No. of } \\
\text { samples }\end{array}$ & Min & Mean & Max & $\begin{array}{l}\text { Standard } \\
\text { deviation }\end{array}$ \\
\hline Modulus of elasticity for timber flanges $(E)$ & $\mathrm{kN} / \mathrm{mm}^{2}$ & 348 & $5 \cdot 36$ & $9 \cdot 49$ & $16 \cdot 73$ & $2 \cdot 18$ \\
\hline Density of timber flanges before oven dried & $\mathrm{kg} / \mathrm{m}^{3}$ & 296 & 347 & 493 & 645 & 50 \\
\hline Density of timber flanges after oven dried & $\mathrm{kg} / \mathrm{m}^{3}$ & 296 & 333 & 437 & 574 & 44 \\
\hline Moisture content of timber flanges before test & $\%$ & 296 & $8 \cdot 70$ & $12 \cdot 06$ & $14 \cdot 70$ & 0.97 \\
\hline Moisture content of timber flanges after test & $\%$ & 251 & $5 \cdot 21$ & $12 \cdot 55$ & $14 \cdot 33$ & 1.40 \\
\hline Modulus of elasticity for $L V L$ flanges $(E)$ & $\mathrm{kN} / \mathrm{mm}^{2}$ & 26 & $10 \cdot 2$ & 11.54 & $12 \cdot 87$ & 0.82 \\
\hline Density of LVL flanges before oven dried & $\mathrm{kg} / \mathrm{m}^{3}$ & 20 & 534 & 556 & 588 & $15 \cdot 14$ \\
\hline Density of LVL flanges after oven dried & $\mathrm{kg} / \mathrm{m}^{3}$ & 20 & 477 & 496 & 525 & $13 \cdot 43$ \\
\hline Moisture content of LVL flanges before test & $\%$ & 104 & $12 \cdot 50$ & $15 \cdot 15$ & $17 \cdot 30$ & $1 \cdot 16$ \\
\hline Moisture content of LVL flanges after test & $\%$ & 20 & $10 \cdot 60$ & $11 \cdot 70$ & $12 \cdot 96$ & 0.92 \\
\hline Plywood shear modulus $(G)$ & $\mathrm{kN} / \mathrm{mm}^{2}$ & 6 & 0.589 & 0.775 & 0.937 & 0.131 \\
\hline Density of plywood webs before oven dried & $\mathrm{kg} / \mathrm{m}^{3}$ & 6 & 473 & 494 & 519 & 17 \\
\hline Density of plywood webs after oven dried & $\mathrm{kg} / \mathrm{m}^{3}$ & 6 & 439 & 456 & 476 & 14 \\
\hline Moisture content of plywood webs & $\%$ & 6 & $7 \cdot 71$ & $8 \cdot 24$ & 9.02 & 0.57 \\
\hline
\end{tabular}

properties arising from the different grain directions, together with the test results from samples tested with face grain both parallel and perpendicular to the span, the modulus of elasticity for the plywood was found to be $11 \cdot 13 \mathrm{kN} / \mathrm{mm}^{2}$ and the equivalent thickness of three-ply plywood with face grain perpendicular to the beam span was $3.40 \mathrm{~mm}$. The effective thickness contributed from the veneers perpendicular to the span is regarded as only 3\% of the thickness from the veneer parallel to the span. From the test results in this case a higher value of 0.067 was found, which is at least twice the value given in the New Zealand standard.

\subsection{Matching the components for the beams}

Unlike the engineered products such as LVL and plywood, timber by nature possesses a high level of material variability. Previous research has shown that the highest level of correlation exists between the modulus of elasticity and the bending strength. ${ }^{5-7}$ Even though the mechanically graded timber MGP 10 with a known modulus of elasticity of $10 \mathrm{kN} /$ $\mathrm{mm}^{2}$ was used, the laboratory tests showed a broad variation from $5 \cdot 4$ to $16 \cdot 7 \mathrm{kN} / \mathrm{mm}^{2}$ (Table 1). As a result, it was decided to reject those boards with $E$ values less than $7 \mathrm{kN} / \mathrm{mm}^{2}$ and to distribute evenly and match the timber sections used as flanges based on the $E$ values for different types of beams.

The timber sections were divided into 11 matched groups for the six short-span profiles. Each group contained 24 matched samples used in pairs for the flanges of 12 beams with the $E$ values equally spreading from low to high. A similar procedure was adopted for the long-span beams, each group comprising six matched samples used in pairs for the flanges of the three beams. This statistical arrangement made it possible to compare the results between the groups and within each group. Since the variability among the tested LVL flanges was relatively insignificant in comparison with the timber ones, they were randomly distributed between the three different profiles.

\subsection{Plywood webs}

The plywood sheets of $1200 \times 1200 \mathrm{~mm}$ were passed through a double-ended tenoner for edge grooving. The tongue-groove profile parallel to the face grain direction of the plywood was used for joining sheets and creating webs for short and long beams. The use of plywood oriented with the face grain perpendicular to the longitudinal axis of the beam was based on the fact that web-crippling performance improves by increasing the number of plies perpendicular to the beam axis. ${ }^{8}$ During the manufacturing process, glue line bonding was checked regularly by carrying out the chisel test in accordance with the recommendations of BS EN $391^{9}$ for testing the Glulam glue line.

\section{TESTING PROCEDURE}

All the short beams were first subjected to non-destructive three-point tests, as shown in Fig. 2(a). Thereafter, the first set of three samples from each group was loaded to failure under four-point loading, as shown in Fig. 2(b). For both tests, midspan deflections relative to the supports were recorded.

Each long beam was first subjected to a series of three-point bending tests over spans of 1450, 2100, 3000 and $4500 \mathrm{~mm}$, as shown in Fig. 3(a). This was followed by testing each beam under four-point bending during which the mid-span deflection relative to the supports was recorded, as shown in Fig. 3(b). In all cases the maximum load applied did not exceed the proportional limit loads or cause any damage to the test beams. Subsequently, three beams from each group were tested to failure in four-point bending over a span of $4350 \mathrm{~mm}$ to determine the maximum bending strength of the beams. The

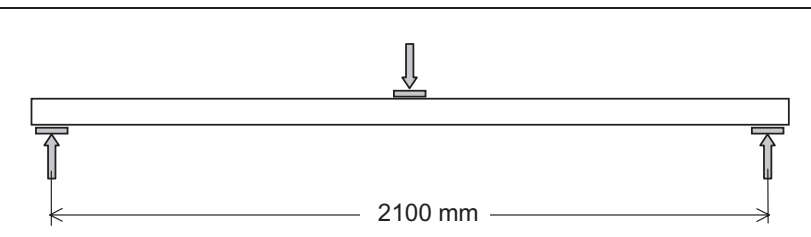

(a)

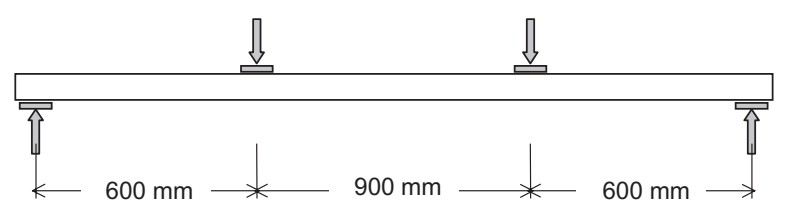

(b)

Fig. 2. Test set-up for short-span beams: (a) three-point bending; (b) four-point bending 


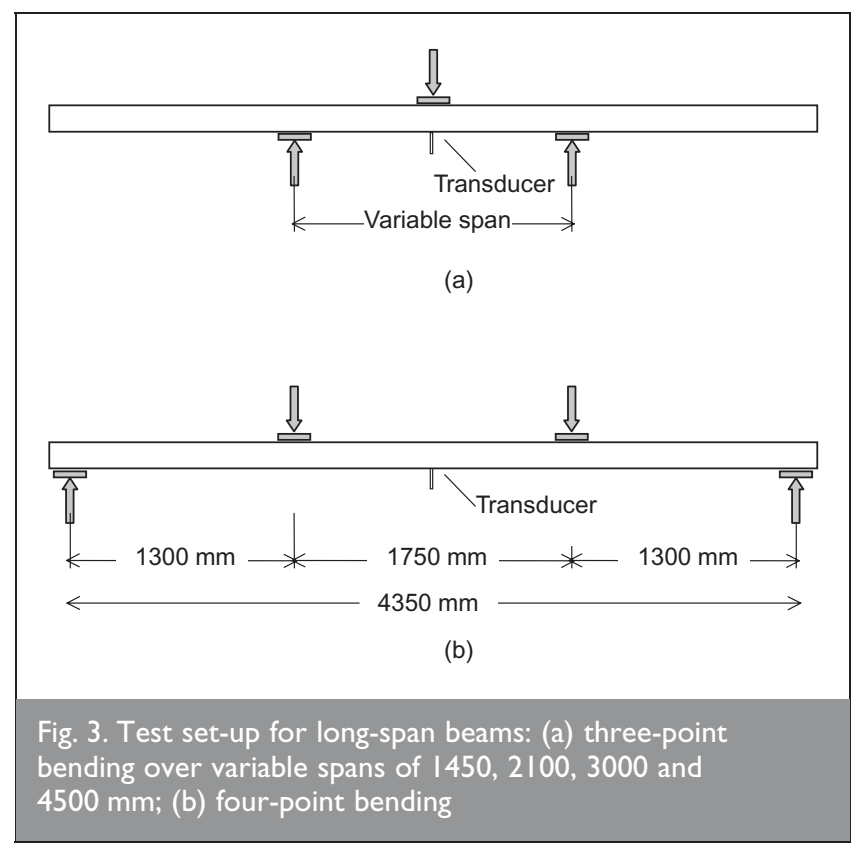

load and the deflection relative to the supports were recorded. Typical short- and long-span beams under four-point bending are shown in Fig. 4. The procedure adopted for testing on both short and long beams was mainly based on the recommendations of BS EN $408^{10}$ and EOTA. ${ }^{11}$

\section{DISCUSSION OF RESULTS}

\section{I. Determination of $E$ and $G$}

Figure 5 shows the apparent modulus of elasticity $(E)$ plotted against the span length $(L)$ for the different types of composite beams subjected to three-point bending. The apparent $E$ values were obtained using the method given in BS EN $408^{10}$ where the effect of the shear load is ignored and the $P / \Delta$ (load over deflection) value from the tests is used in the conventional formula

$$
E=\frac{L^{3}}{48 I}\left(\frac{P}{\Delta}\right)
$$

From the test results, it can be seen that as the span $L$ increases, the effect of shear decreases and hence the apparent $E$ values for the beams in bending approach the true values.

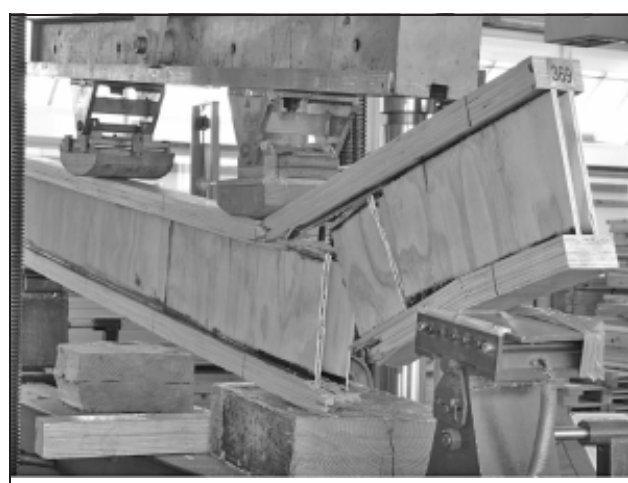

(a)
Fig. 5 also shows that shear not only affects the deformation characteristics of composite beams such as I or box beams but also affects solid sections such as LVL and Glulam beams. LVL is seen to have a sharper slope than the Glulam. In other words, the effect of the shear deflection is more pronounced in LVL. The lay-up of the LVL veneers may explain this result. Veneers of LVL are laid up in such a way that the lower-grade veneers are positioned in the inner core, and higher grade ones on the outer face. ${ }^{12}$

In order to examine the effect of shear on the deflection of the beams, it was assumed that $E$ and shear modulus $(G)$ remain constant during loading, irrespective of loading method and span length. By considering each beam over two different spans or loading types, a pair of linear equations was derived for determining the $E$ and $G$ values of the composite sections. Nine combinations in total were considered, as detailed in Table 2. The first six combinations included the results from three-point bending tests for spans $L_{1}$ and $L_{2}$. For these combinations, $E$ and $G$ are found by solving the following pair of equations, where the deflection per unit load is the sum of the bending and shear components

\begin{tabular}{|l|l}
\hline 2 & $\frac{\Delta_{1}}{P_{1}}=\frac{L_{1}^{3}}{48 E I}+\frac{\alpha L_{1}}{4 G A} \quad$ and $\quad \frac{\Delta_{2}}{P_{2}}=\frac{L_{2}^{3}}{48 E I}+\frac{\alpha L_{2}}{4 G A}$ \\
\hline
\end{tabular}

where $\Delta_{1} / P_{1}$ and $\Delta_{2} / P_{2}$ are the corresponding mid-span deflections per unit applied load, $L_{1}$ and $L_{2}$ are two different spans of the beam under three-point bending, $I$ is the second moment of area and $\alpha$ is the shear factor.

For the remaining three combinations in Table 2, three-point bending with span of $L_{1}$ and four-point bending with span of $L_{2}$ were adopted and $E$ and $G$ are determined from

$3 \frac{\Delta_{1}}{P_{1}}=\frac{L_{1}^{3}}{48 E I}+\frac{\alpha L_{1}}{4 G A}$ and $\frac{\Delta_{2}}{P_{2}}=\frac{L_{2}^{3}}{6 E I}\left[\frac{3 a}{4 L_{2}}-\left(\frac{a}{L_{2}}\right)^{3}\right]+\frac{\alpha a}{G A}$

where $a$ is the distance between the supports and the load head in the four-point loaded beams. Shear factors are calculated by using an approximate method known as Roark's formula ${ }^{13}$

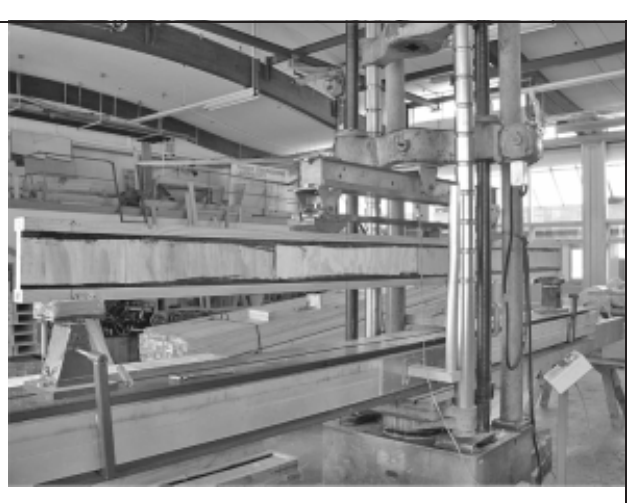

(b)

Fig. 4. Typical beams tested over $2.1 \mathrm{~m}$ and $4.35 \mathrm{~m}$ span: (a) short-span double l-beam; (b) longspan double I-beam 


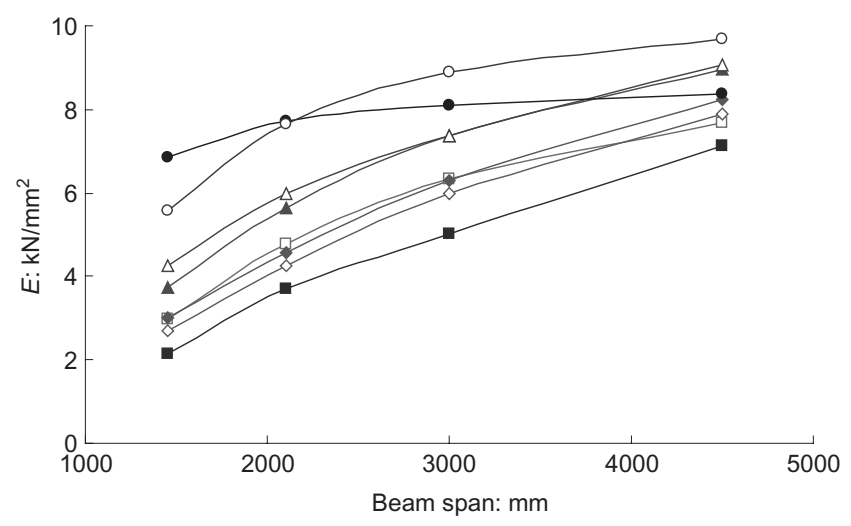

\begin{tabular}{|c|}
\hline$\rightarrow-$ I-beam $(E)$ \\
\hline$\neg$-Double I-beam $(E)$ \\
\hline$\multimap-$ Recessed beam $(E)$ \\
\hline$\diamond$ Box beam $(E)$ \\
\hline$\rightarrow-$ Boxed I-beam $(E)$ \\
\hline$\triangle$ Boxed double l-beam $(E)$ \\
\hline$\bullet-\operatorname{Glulam}(E)$ \\
\hline$\multimap-\operatorname{LVL}(E)$ \\
\hline
\end{tabular}

Fig. 5. Modulus of elasticity plotted against span for three-point bending

\begin{tabular}{|c|c|c|c|c|}
\hline \multicolumn{5}{|c|}{ Different testing combinations } \\
\hline No. & Testing arrangements & Span: mm & Testing arrangements & Span: mm \\
\hline I & 3-point bending & 1450 & 3-point bending & 2100 \\
\hline 2 & & 1450 & & 3000 \\
\hline 3 & & 1450 & & 4500 \\
\hline 4 & & 3000 & & 4500 \\
\hline 5 & & 2100 & & 3000 \\
\hline 6 & & 2100 & & 4500 \\
\hline 7 & & 1450 & 4-point bending & 4350 \\
\hline 8 & & 2100 & & 4350 \\
\hline 9 & & 3000 & & 4350 \\
\hline
\end{tabular}

$4 \quad \alpha=\left[1+\frac{3\left(D_{2}^{2}-D_{1}^{2}\right) D_{1}}{2 D_{2}^{3}}\left(\frac{t_{2}}{t_{1}}-1\right)\right] \frac{4 D_{2}^{2}}{10 r^{2}}$

where $D_{1}$ is the distance from the neutral axis to the nearest surface of the flange, $D_{2}$ is the distance from the neutral axis to the extreme fibre, $t_{1}$ is the thickness of the web, $t_{2}$ is the width of the flange and $r$ is the radius of gyration of section with respect to the neutral axis. This formula was found to be very accurate when compared with an exact method based on strain energy principles. The values of shear factors for all crosssections are summarised in Table 3. The calculated values of the cross-sectional area $A$ and second moment of area $I$ using the transformed-section method are also listed in Table 3.

The $E$ and $G$ values of the long beams with timber and LVL flanges, obtained from nine different combinations, are given in Figs 6(a) and 6(b) while for the solid LVL and Glulam beams these are shown in Fig. 6(c). In Table 4, the $E$ values of timber flanges prior to manufacture are compared with the $E$ values of the composite beams. The reduction in $E$ values in comparison with the $E$ values of the corresponding timber flanges ranged from $0 \%$ for the box beams, boxed I-beams and boxed double I-beams to 6, 7 and 14\% for double I-beams, recessed beams and I-beams, respectively. This may be attributed to the rigidity

\begin{tabular}{|c|c|c|c|c|}
\hline & $\alpha$ : Roark's formula & $\alpha$ : exact calculation & A: $10^{4} \mathrm{~mm}^{2}$ & I: $10^{8} \mathrm{~mm}^{4}$ \\
\hline I-beam & 3.59 & 3.64 & 0.99 & 1.23 \\
\hline Double I-beam & $2 \cdot 27$ & $2 \cdot 38$ & 1.19 & 1.25 \\
\hline Recessed beam & $2 \cdot 34$ & $2 \cdot 45$ & $1 \cdot 17$ & 1.25 \\
\hline Box beam & $2 \cdot 82$ & $3 \cdot 32$ & 1.40 & 1.36 \\
\hline Boxed I-beam & $2 \cdot 32$ & $2 \cdot 77$ & 1.56 & 1.38 \\
\hline Boxed double I-beam & 2.04 & $2 \cdot 49$ & 1.76 & 1.40 \\
\hline LVL I-beam & 3.99 & 4.02 & 0.96 & 1.22 \\
\hline LVL double I-beam & $2 \cdot 49$ & $2 \cdot 58$ & $1 \cdot 13$ & $1 \cdot 25$ \\
\hline LVL boxed I-beam & $2 \cdot 43$ & $2 \cdot 83$ & 1.46 & 1.36 \\
\hline Glulam beam & - & 1.2 & $2 \cdot 23$ & 1.03 \\
\hline LVL beam & - & $1 \cdot 2$ & $2 \cdot 79$ & $2 \cdot 12$ \\
\hline
\end{tabular}



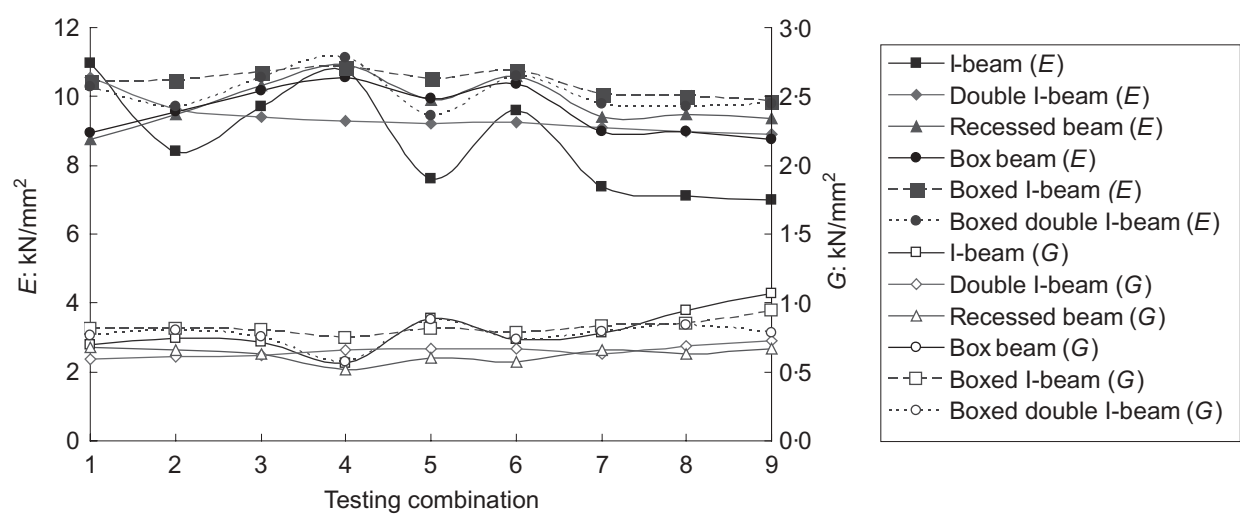

(a)

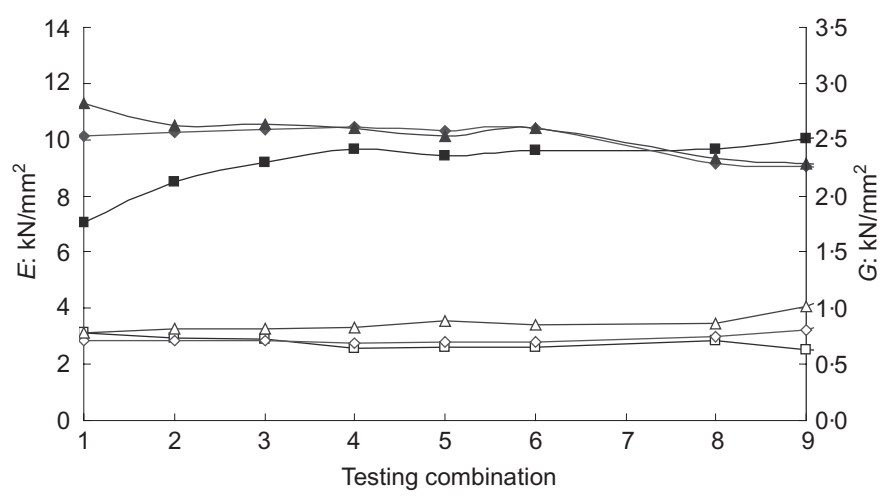

$$
\begin{aligned}
& \rightarrow \text { LVL I-beam }(E) \\
& \rightarrow \text { LVL double I-beam }(E) \\
& - \text { LVL boxed I-beam }(E) \\
& \square-\text { LVL I-beam }(G) \\
& \diamond-\text { LVL double I-beam }(G) \\
& \triangleleft \text { LVL boxed I-beam }(G)
\end{aligned}
$$

(b)

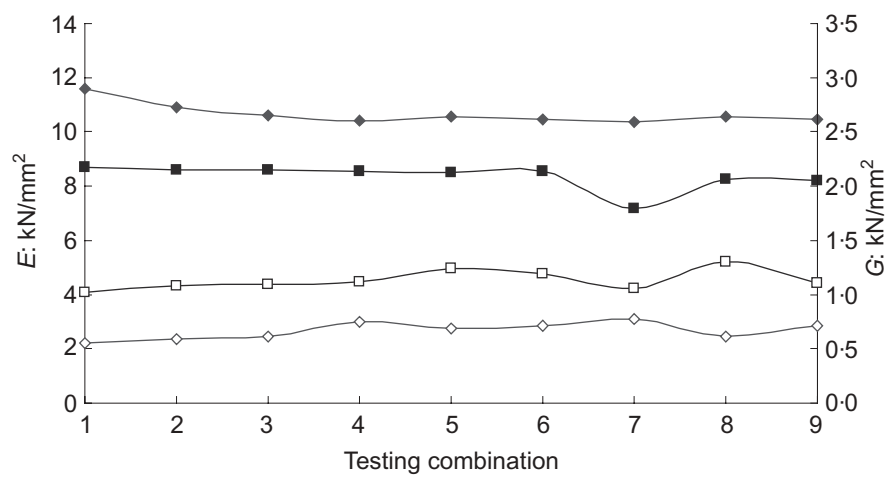

$$
\begin{aligned}
& - \text { Glulam }(E) \\
& - \text { LVL }(E) \\
& \rightarrow-\text { Glulam }(G) \\
& \multimap-\operatorname{LVL}(G)
\end{aligned}
$$

(c)

Fig. 6. $E$ and $G$ values for different combinations: (a) manufactured beams with timber flanges; (b) manufactured beams with LVL flanges; (c) Glulam and LVL beams - ready-made sections

of the beam. The results in Table 4 show that as the rigidity of the beams increases, the reduction of the elastic modulus decreases. In other words, the rigidity of the beam affects bending test results.

\subsection{Failure modes and ultimate strength}

In general, the failure of the short beams, with the exception of the boxed double I-beam, started in plywood webs. This was followed by failure of the bottom flange, which often occurred at the loading point (Fig. 7). Unlike the rest of the beams, flexural failure of the timber flange in the boxed double Ibeam caused the beam failure. Maximum load-deflection curves for the various profiles, which are tested under fourpoint bending over a $2100 \mathrm{~mm}$ span are given in Fig. 8 .

Experimental tests show that additional webs would increase the loading capacity of beams significantly, although this is not proportionate to the number of webs. This can be explained by the material variability and uneven distribution of the load between the webs. Thus the webs would not fail simultaneously and this in turn results in uneven distribution of the load. In the case of boxed I-beams, in addition, finite element analysis shows that the middle web sustains a larger proportion of the load than the side webs from the beginning.

Flexural failure was the dominant cause of collapse in the long beams including the double I-beams, recessed beams, box beams, boxed I-beams, boxed double I-beams and LVL boxed I-beams, while in the I-beam, LVL I-beams and LVL double I-beams the beams collapsed owing to web failure. It is observed that the short-span and long-span I-beams and LVL I-beams, after reaching the maximum capacity, exhibited 


\begin{tabular}{|c|c|c|c|}
\hline \multirow[t]{2}{*}{ Profile } & \multicolumn{2}{|c|}{ Mean value of $E$} & \multirow{2}{*}{$\begin{array}{c}\begin{array}{c}\text { Timber flange versus } \\
\text { fabricated beam }\end{array} \\
\text { Reduction: \% }\end{array}$} \\
\hline & $\begin{array}{c}\text { Timber flanges: } \\
\mathrm{kN} / \mathrm{mm}^{2}\end{array}$ & $\begin{array}{l}\text { Fabricated beam: } \\
\qquad \mathrm{kN} / \mathrm{mm}^{2}\end{array}$ & \\
\hline I-beam & 10.16 & 8.72 & 14 \\
\hline Double I-beam & 9.98 & $9 \cdot 37$ & 6 \\
\hline Recessed beam & 10.55 & 9.80 & 7 \\
\hline Box beam & 9.50 & 9.58 & NS \\
\hline Boxed I-beam & 10.20 & 10.41 & NS \\
\hline Boxed double I-beam & 10.10 & 10.11 & NS \\
\hline
\end{tabular}

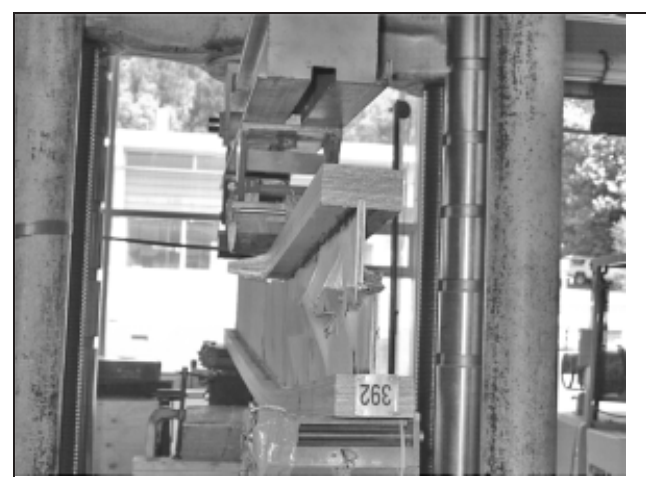

(a)

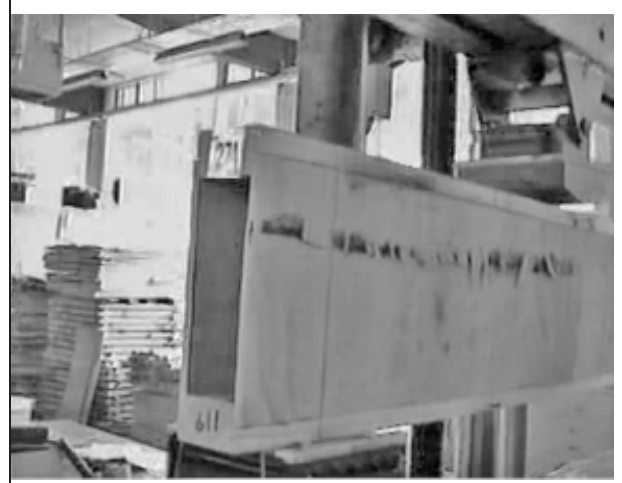

(c)

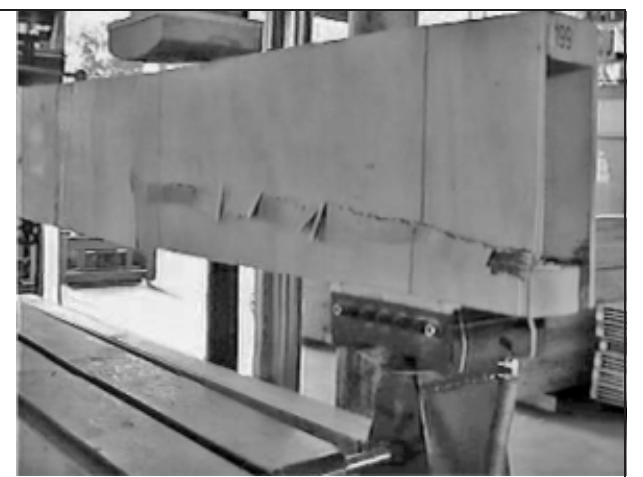

(b)

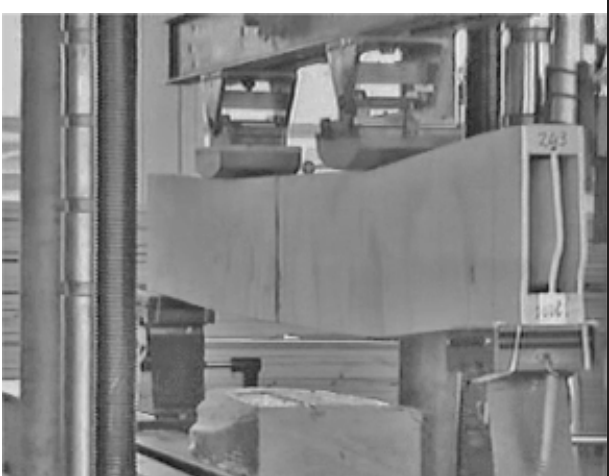

(d)

Fig. 7. Failure modes for various beams under four-point bending over 2.I $\mathrm{m}$ span: (a) LVL Ibeam; (b) box beam; (c) recessed beam; (d) boxed I-beam

considerable ductility as crushing of the ply-web continued. Fig. 9 shows the maximum load deflection curves for the various profiles tested under four-point bending over a $4350 \mathrm{~mm}$ span.

The test results for short and long beams for each profile are presented in Tables 5 and 6 . All results in these tables are based on the four-point bending tests except for one column, which gives the slope of the $P-\Delta$ curve for the three-point bending tests. Using the I-beam as a reference, the use of additional webs to create a double I-beam, recessed beam or box beam increased the loading capacity of the short-span beams by up to $83 \%$ and that of the long-span beams by up to $57 \%$. The unit weight of the beams, however, increased only by $20 \%$ for the double I-beam and recessed beam and 37\% for the box beam. Similarly, adding additional webs in the LVL flanged beams increased the loading capacity by 99 and 44\% for the short and long beams, respectively, while the unit weight of the beams increased by only $16 \%$.

Comparison of two-web beams (recessed beam, double Ibeam and box beam) with the three-web beams (boxed Ibeam) under similar loading conditions shows that the additional webs increased the loading capacity by $28 \%$ for the short beams and 16\% for the long beams, while the unit weight of the beams increased by 30\% for the recessed beams and double I-beams and 15\% for the box beams. Similarly, the loading capacity for the short and long LVL flanged beams was enhanced by 35 and 53\%, respectively, while the unit weight of the beams increased only by $27 \%$. Comparison of the results of the boxed I-beam with the boxed double I-beam shows no significant improvement in 


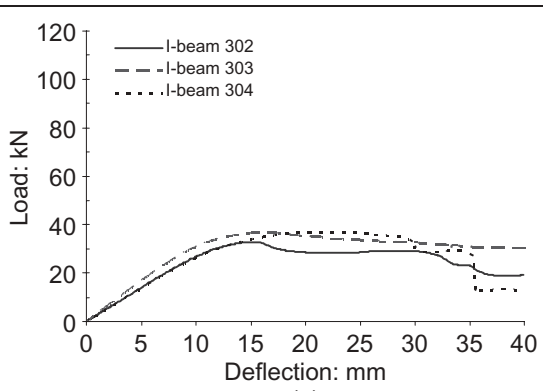

(a)

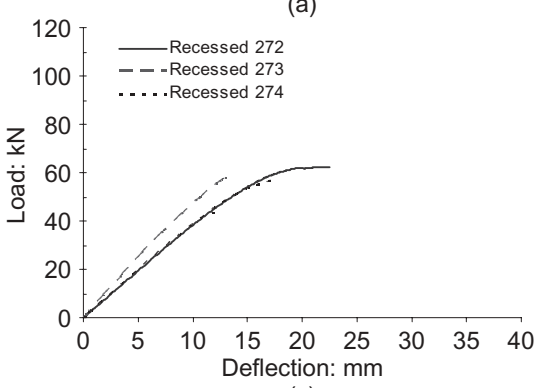

(c)

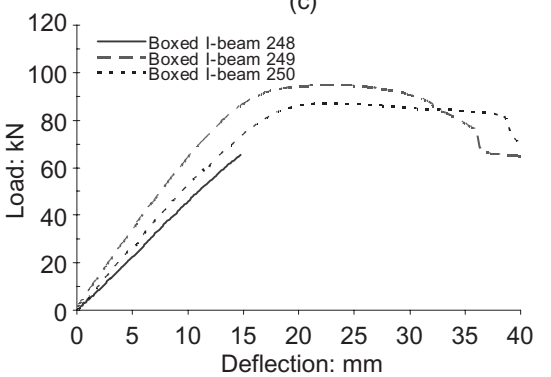

(e)

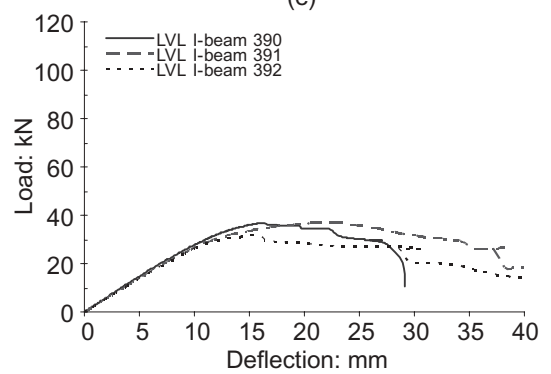

(g)

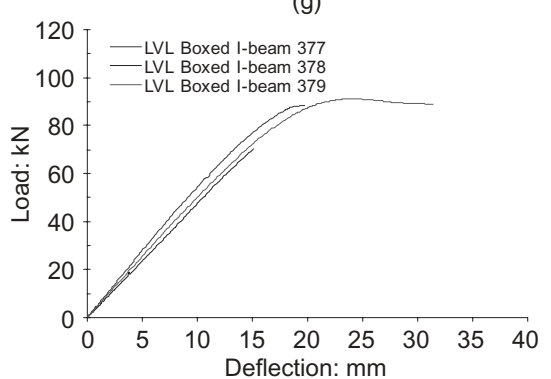

(i)

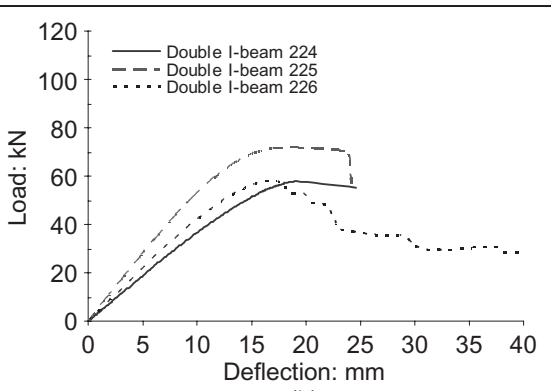

(b)

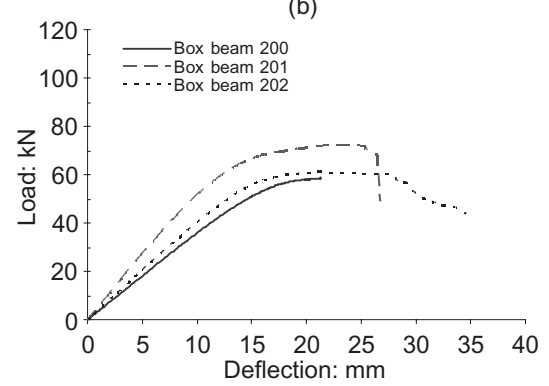

(d)

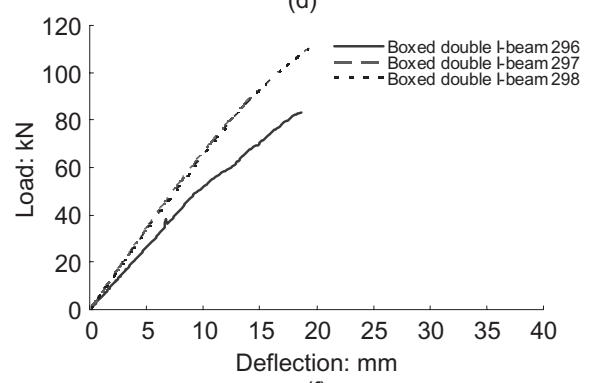

(f)

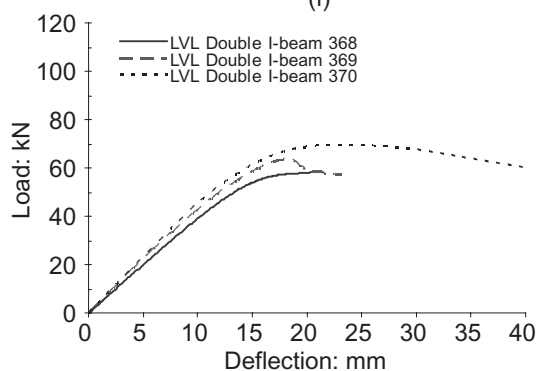

(h)

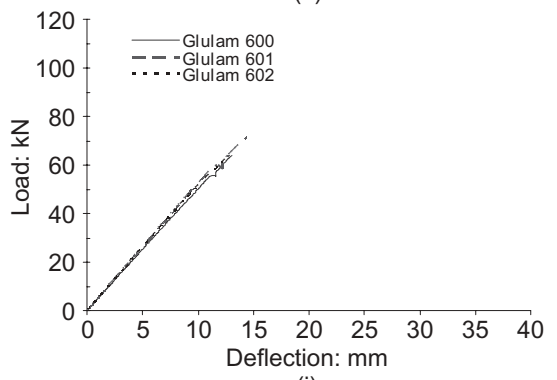

(j)

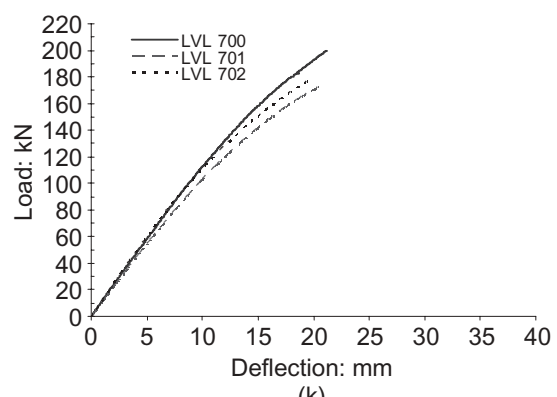

(k)

Fig. 8. Load-deflection relationships for short beams of varied profiles under four-point bending: (a) I-beams, average max. load $35 \mathrm{kN}$; (b) double l-beams, average max. load $63 \mathrm{kN}$; (c) recessed beams, average max. load $59 \mathrm{kN}$; (d) box beams, average max. load 64 kN; (e) boxed I-beams, average max. load 82 kN; (f) boxed double l-beams, average max. load 96 kN; (g) LVL l-beams, average max. load 35 kN; (h) LVL double I-beams, average max. load 67 kN; (i) LVL boxed I-beams, average max. load 9 I kN; (j) Glulam, average max. load 67 kN; (k) LVL, average max. load 183 kN 


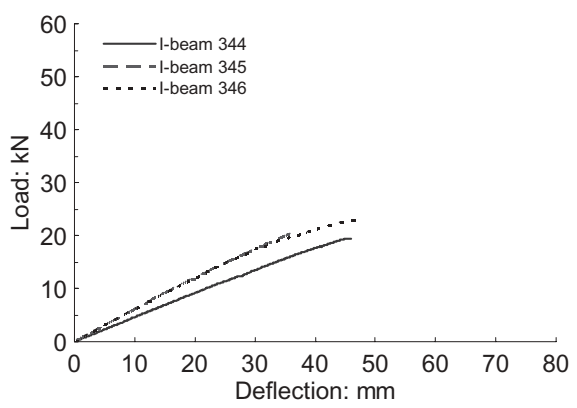

(a)

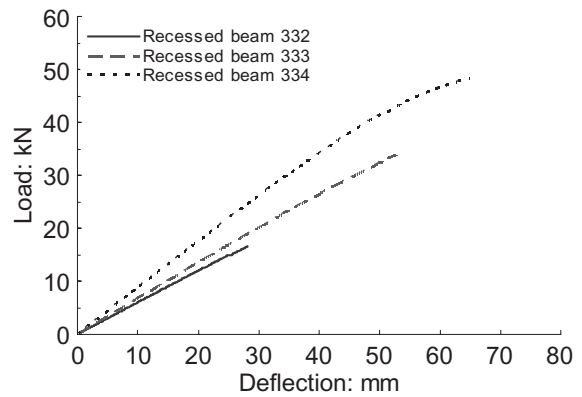

(c)

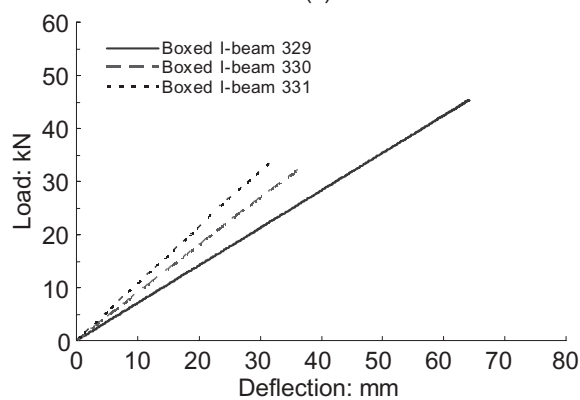

(e)

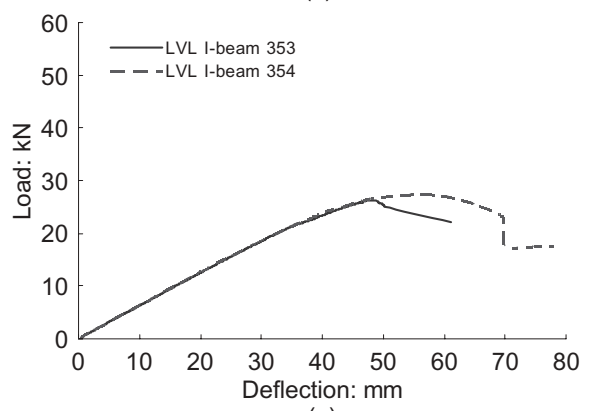

(g)

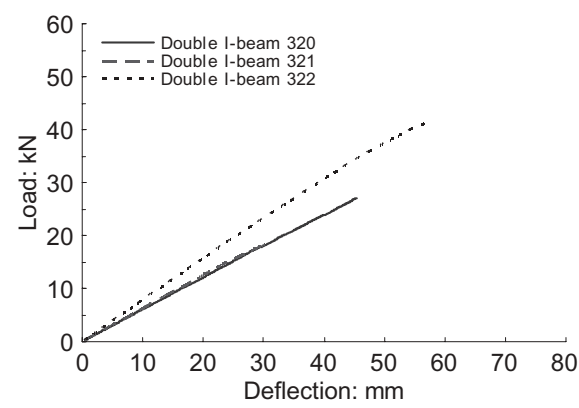

(b)

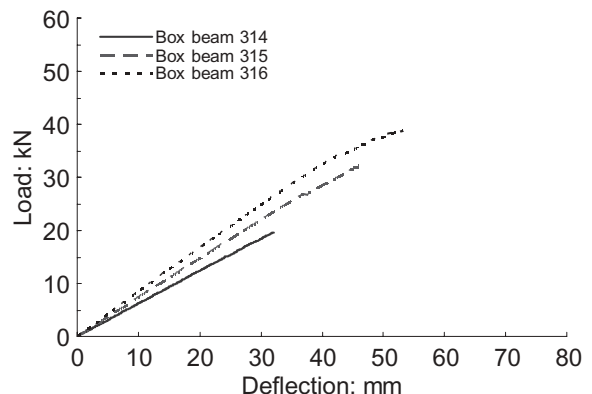

(d)

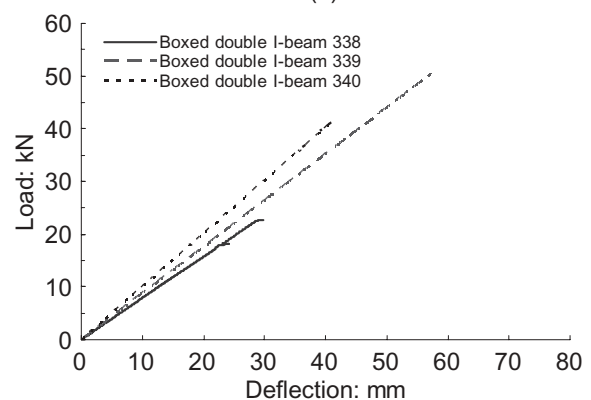

(f)

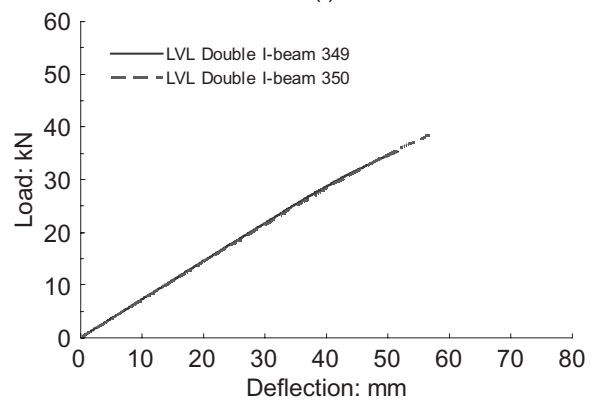

(h)

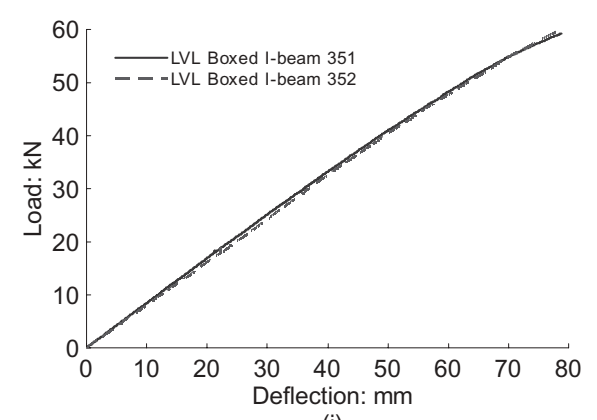

(i)

Fig. 9. Load-deflection curves for long-span beams of varied profiles under four-point bending: (a) I-beams, average max. load $21 \mathrm{kN}$; (b) double l-beams, average max. load $29 \mathrm{kN}$; (c) recessed beams, average max. load $33 \mathrm{kN}$; (d) box beams, average max. load 30 kN; (e) boxed l-beam, average max. load 37 kN; (f) boxed double l-beams, average max. load 38 kN; (g) LVL I-beams, average max. load 27 kN; (h) LVL double I-beams, average max. load 39 kN; (i) LVL boxed l-beam, average max. load 60 kN

bending capacity, as this was restricted by the flange strength.

The structural performance of the short beams with LVL flanges was reasonably close to that of timber flanged beams (Table 5) while their performances in long beams were significantly improved (Table 6). Enhancement in the structural performance of the LVL flanged beams is attributed to 


\begin{tabular}{|c|c|c|c|c|c|c|c|c|c|c|}
\hline \multirow[t]{2}{*}{ Profile } & \multirow{2}{*}{$\begin{array}{l}\text { Beam weight: } \\
\mathrm{kg} / \mathrm{m}\end{array}$} & \multicolumn{2}{|c|}{ Slope of $\mathrm{P}-\Delta$ curves } & \multirow{2}{*}{$\begin{array}{l}\text { Max load } \\
\text { Mean: } \\
\text { kN }\end{array}$} & \multirow{2}{*}{$\begin{array}{l}\text { Mid span deflection } \\
\text { at max load: } \\
\text { mm }\end{array}$} & \multirow{2}{*}{$\begin{array}{l}M_{\max }: \\
\mathrm{kNm}\end{array}$} & \multirow{2}{*}{$\begin{array}{c}\sigma_{\mathrm{m}}: \\
\mathrm{N} / \mathrm{mm}^{2}\end{array}$} & \multirow{2}{*}{$\begin{array}{c}\tau, \\
\text { flange: } \\
\mathrm{N} / \mathrm{mm}^{2}\end{array}$} & \multirow{2}{*}{$\begin{array}{c}\tau_{\text {panel }} \\
\text { web: } \\
\mathrm{N} / \mathrm{mm}^{2}\end{array}$} & \multirow{2}{*}{$\begin{array}{c}\tau_{\text {rolling, }} \\
\text { web: } \\
\mathrm{N} / \mathrm{mm}^{2}\end{array}$} \\
\hline & & $\begin{array}{l}\text { 3-P bending: } \\
\text { kN/mm }\end{array}$ & $\begin{array}{l}\text { 4-P bending: } \\
\mathrm{kN} / \mathrm{mm}\end{array}$ & & & & & & & \\
\hline I-beam & 4.9 & $2 \cdot 128$ & $3 \cdot 259$ & 35 & 18 & 10.62 & $12 \cdot 47$ & 0.79 & $6 \cdot 16$ & 4.94 \\
\hline Double I-beam & $5 \cdot 9$ & 3.082 & 4.426 & 63 & 18 & 18.85 & $21 \cdot 56$ & $1 \cdot 37$ & 5.85 & $4 \cdot 35$ \\
\hline Recessed beam & $5 \cdot 9$ & $2 \cdot 898$ & 3.990 & 59 & 20 & $17 \cdot 77$ & $20 \cdot 34$ & $1 \cdot 29$ & $5 \cdot 58$ & 4.05 \\
\hline Box beam & $6 \cdot 7$ & $3 \cdot 150$ & $4 \cdot 291$ & 64 & 22 & $19 \cdot 22$ & 19.87 & 1.26 & 6.63 & $2 \cdot 32$ \\
\hline Boxed I-beam & $7 \cdot 7$ & 3.715 & $5 \cdot 118$ & 82 & 20 & $24 \cdot 72$ & $25 \cdot 01$ & 1.58 & 6.09 & $2 \cdot 36$ \\
\hline Boxed double I-beam & 8.7 & $4.54 I$ & $6 \cdot 142$ & 96 & 19 & 28.66 & $29 \cdot 14$ & 1.85 & $6 \cdot 30$ & 1.91 \\
\hline LVL I-beam & $5 \cdot 5$ & 2.029 & $2 \cdot 827$ & 35 & 19 & 10.56 & $12 \cdot 52$ & 0.79 & 8.86 & $3 \cdot 32$ \\
\hline LVL double I-beam & $6 \cdot 4$ & $3 \cdot 223$ & $4 \cdot 558$ & 67 & 23 & $20 \cdot 00$ & $23 \cdot 29$ & 1.48 & 8.91 & 3.09 \\
\hline LVL boxed I-beam & $8 \cdot 1$ & $4 \cdot 125$ & $5 \cdot 794$ & 91 & 26 & $27 \cdot 25$ & $29 \cdot 16$ & 1.85 & $9 \cdot 23$ & 1.82 \\
\hline Glulam beam ${ }^{\prime}$ & 10.6 & 3.676 & 4.964 & 67 & 13 & 19.96 & $22 \cdot 87$ & $2 \cdot 27$ & & \\
\hline LVL beam" & $15 \cdot 3$ & $7 \cdot 626$ & $10 \cdot 250$ & 183 & 19 & 54.93 & 39.11 & 5.03 & & \\
\hline
\end{tabular}

I: Glulam beams with dimensions of $94 \times 235 \mathrm{~mm}$

II: LVL beams with dimensions of $90 \times 302 \mathrm{~mm}$

Table 5. Mechanical properties of short-span beams

\begin{tabular}{|c|c|c|c|c|c|c|c|c|c|c|}
\hline \multirow[b]{2}{*}{ Beam span $4.35 \mathrm{~m}$} & \multicolumn{2}{|c|}{ Slope of $\mathrm{P}-\Delta$ curves } & \multirow{2}{*}{$\begin{array}{l}\text { Max load } \\
\text { ave: } \\
\text { kN }\end{array}$} & \multirow{2}{*}{$\begin{array}{c}\text { Mid-span deflection } \\
\text { at max load: } \\
\mathrm{mm}\end{array}$} & \multirow{2}{*}{$\begin{array}{c}\mathrm{El}: \\
10^{12} \mathrm{Nmm}^{2}\end{array}$} & \multirow{2}{*}{$\begin{array}{l}M_{\max }: \\
\mathrm{kNm}\end{array}$} & \multirow{2}{*}{$\begin{array}{c}\sigma_{\mathrm{m}}: \\
\mathrm{N} / \mathrm{mm}^{2}\end{array}$} & \multirow{2}{*}{$\begin{array}{c}\tau, \\
\text { flange: } \\
\mathrm{N} / \mathrm{mm}^{2}\end{array}$} & \multirow{2}{*}{$\begin{array}{c}\tau_{\text {panel }} \\
\text { web: } \\
\mathrm{N} / \mathrm{mm}^{2}\end{array}$} & \multirow{2}{*}{$\begin{array}{l}\tau_{\text {rolling, }} \\
\text { web: } \\
\mathrm{N} / \mathrm{mm}^{2}\end{array}$} \\
\hline & $\begin{array}{l}\text { 3-P bending: } \\
\mathrm{kN} / \mathrm{mm}\end{array}$ & $\begin{array}{l}\text { 4-P bending: } \\
\mathrm{kN} / \mathrm{mm}\end{array}$ & & & & & & & & \\
\hline I-beam & 0.460 & 0.582 & 21 & 42 & 1.070 & $13 \cdot 13$ & $15 \cdot 52$ & 0.45 & 4.46 & $2 \cdot 19$ \\
\hline Double I-beam & 0.507 & 0.716 & 29 & 44 & $1 \cdot 174$ & 18.87 & 21.85 & 0.64 & $3 \cdot 38$ & 1.57 \\
\hline Recessed beam & 0.542 & 0.733 & 33 & 48 & $1 \cdot 225$ & $21 \cdot 37$ & 24.80 & 0.73 & 4.02 & 1.68 \\
\hline Box beam & 0.566 & 0.755 & 30 & 43 & $1 \cdot 307$ & 19.65 & $20 \cdot 89$ & 0.61 & $3 \cdot 71$ & 0.87 \\
\hline Boxed I-beam & 0.651 & 0.911 & 37 & 40 & 1.433 & $24 \cdot 14$ & $25 \cdot 42$ & 0.74 & $3 \cdot 39$ & 0.79 \\
\hline Boxed double I-beam & 0.671 & 0.905 & 38 & 39 & 1.420 & 24.83 & $25 \cdot 64$ & 0.75 & $2 \cdot 72$ & 0.69 \\
\hline LVL I-beam & 0.427 & 0.652 & 27 & 52 & 1.134 & 17.45 & 20.68 & 0.60 & $6 \cdot 76$ & $2 \cdot 53$ \\
\hline LVL double I-beam & 0.546 & 0.719 & 39 & 60 & 1.229 & $25 \cdot 64$ & 29.86 & 0.87 & $5 \cdot 27$ & 1.83 \\
\hline LVL boxed I-beam & 0.625 & 0.821 & 60 & 75 & $1 \cdot 365$ & 38.88 & $41 \cdot 60$ & 1.22 & 6.08 & $1 \cdot 20$ \\
\hline Glulam beam & 0.445 & 0.603 & 42 & - & 0.85 & 27.59 & 39.62 & 1.45 & & \\
\hline LVL beam & 1.058 & 1.499 & 100 & - & $2 \cdot 16$ & $67 \cdot 67$ & $47 \cdot 29$ & $2 \cdot 85$ & & \\
\hline
\end{tabular}


neutralising the natural timber defects by dispersing them randomly during the manufacturing process and this effect is more pronounced as the span is increased. A comparison of the load-deformation characteristics shows a similar performance in stiffness for the beams with timber and LVL flanges up to service load levels, while at higher load levels timber flanged beams often experienced a loss in strength and stiffness owing to natural defects within the timber. This problem could, however, be resolved by proof loading the timber flanges before fabricating the beams.

\subsection{Prediction of the failure mode}

Maximum bending and shear stresses occurred in the beam flanges and webs, respectively, and these are shown together with the corresponding bending and panel shear strengths in Tables 5 and 6, respectively. The characteristic values of shear strength for panel shear and rolling shear on plywood are given as 4.7 and $1.9 \mathrm{~N} / \mathrm{mm}^{2}$, while the characteristic values of bending strength are given as 25.4 and $38 \mathrm{~N} / \mathrm{mm}^{2}$ for timber and LVL flanges, respectively. ${ }^{2}$

The panel shear stresses in the short beams exceed the panel shear strength in all cases. The rolling shear stresses also exceed the corresponding strength for all cases except the boxed double I-beams and LVL boxed I-beams. The bending stress exceeds the bending strength only in the boxed double Ibeams. For all the beams except the boxed double I-beams, the actual failure resulted from shear. It can be seen from the stress calculations that the combined panel shear and rolling shear caused the beam to fail. In the case of the boxed double Ibeams, both the flexural and shear strengths are exceeded. According to the stress calculations, at a load level of $71 \mathrm{kN}$, the shear stress in the boxed double I-beam web is equal to the maximum strength of plywood at $4.7 \mathrm{~N} / \mathrm{mm}^{2}$, while the bending stress in timber flanges is $22 \mathrm{~N} / \mathrm{mm}^{2}$, which is lower than its ultimate strength of $25 \mathrm{~N} / \mathrm{mm}^{2}$. the beam is therefore expected to fail in shear. The actual mode of failure in this case, however, is in flexure. The flexural stresses are close enough to the strength, which casts some doubt as to which mode of failure to predict for this beam. In the case of the LVL boxed I-beam, the panel shear stress exceeds the characteristic strength so as to cause the failure.

Examination of the stress and strength results for the longspan beams given in Table 6 shows that, with the exception of the I-beam, all the timber flanges failed in flexural bending, which is consistent with the failure mode observed in the laboratory. The stress results indicate that a combination of panel shear and rolling shear caused the failure in the I-beams and LVL I-beams, while failure in LVL double I-beams that initiated in plywood webs was attributed to panel shear. Flexural failure in LVL flange, however, caused the failure in LVL boxed I-beams. This failure cannot be predicted since, according to the calculations given in Table 6, when the load reaches $46 \mathrm{kN}$, the plywood web stress is at the ultimate strength of $4.7 \mathrm{~N} / \mathrm{mm}^{2}$ while the stress in the LVL flange reaches $33 \mathrm{~N} / \mathrm{mm}^{2}$, which is lower than its ultimate strength of $38 \mathrm{~N} / \mathrm{mm}^{2}$. As a result, panel shear should cause the failure while flexural failure was observed during the testing. This case is similar to the short-span boxed double I-beam described above.
The rolling shear stress is directly affected by the gluing area for both short and long beams. Consequently, increasing the grooving depth of I-beam, double I-beam, LVL I-beam and LVL double I-beam can enhance the rolling shear strength so as to enhance the overall structural performance of the beams. This will be particularly effective for long-span I-beams because rolling shear is the dominant factor controlling the strength of these beams.

\section{CONCLUSIONS}

(a) Experimental results show that shear has a significant effect on the total deflection of the beams and this is also extended to the solid sections such as LVL.

(b) The modulus of elasticity and shear modulus can be calculated by solving the pair of deflection:load equations, from a combination of two different tests. In order to achieve a reliable result, however, it is necessary to use a number of different combinations.

(c) The mean value of the elastic modulus calculated for the fabricated beams is lower than those measured for their flanges.

(d) The bending capacity of lightweight beams made with LVL flanges is more consistent compared with similar beams made with timber flanges as natural defects are dispersed harmlessly.

(e) Creating the double I-beams or boxed I-beams by simply employing additional webs significantly enhanced the bending capacity of the beams as well as their shear capacity while at the same time preserving the high strength to weight ratio.

( $f$ ) Boxed I-beams with plywood webs and timber flanges or LVL flanges are found to be the optimum design among the fabricated beams in terms of structural performance and ease of manufacturing.

(g) It is shown that, in most cases, it is possible to predict the failure mode by comparing the theoretical stresses with the characteristic values of the components.

\section{ACKNOWLEDGEMENTS}

The authors would like to acknowledge the Royal Academy of Engineering and Royal Society of Edinburgh for funding this project and also the New Zealand Forest Research Institute for providing the testing facilities and technician supports. The authors are also grateful for the assistance and support provided by Fletcher Challenge, Lakeland Timber Processors and ORICA Adhesives \& Resins.

\section{REFERENCES}

1. Standards Australia/Standards NeW Zealand. PlywoodStructural. SAI Global, Sydney, 1994, AS/NZS 2269.

2. Standards NeW Zealand. Timber Structures, Standard. SN2, Wellington, 1993, NZS 3603.

3. ORICA. Adhesives and Resins, SYLVIC R15/SYLVIC L5 Technical Data Sheet. ORICA, Melbourne, 2003.

4. Standards Australia/Standards New Zealand. Timber Stress Graded in Grade and Stiffness Evaluation. SAI Global, Sydney, 1992, AS/NZS 4063.

5. HOFFMeyer P., Brauner L., BOSTROM L. and SOlLi K. H. Tensile strength of Glulam laminations of Nordic spruce. Proceedings of the Pacific Timber Engineering Conference, Rotorua, New Zealand, 1999. 
6. JOHANSSON C.-J., BRUNDIN J. and GRUBER R. Stress Grading of Swedish and German Timber. A Comparison of Machine Stress Grading and Three Visual Grading Systems. Swedish National Testing and Research Institute, Borås, 1992.

7. LACKNER R. and FosLIE M. Gran fra Vestlandet Styrke och sortering. Norwegian Institute of Wood Technology, Oslo, 1988, Report, 74 pp.

8. Leichti R. J., Falk R. H. and Laufenberg T. H. Prefabricated wood composite I-beams, Wood and Fiber Science, 1990, 22, No. 1, 62-79.

9. BRITISH STANDARDS INSTITUTION. Glued Laminated Timber: Delamination Test of Glue Lines. BSI, Milton Keynes, 2001, BS EN 391.
10. BRITISH STANDARDS InSTITUTION. Timber Structures: Structural Timber and Glued Laminated TimberDetermination of some Physical and Mechanical Properties. BSI, Milton Keynes, 1995, BS EN 408.

11. EUROPEAN ORGANISATION FOR TeChNiCAL APPROVALS. Test Methods for Light Composite Beams and Columns. EOTA, Brussels, 2000, Technical report TR 002, 8pp.

12. Sherman Nelson, P. E. Engineered Wood Products, A Guide for Specifiers, Designers and Users, Structural Composite Lumber. PFS Research Foundation, Madison, WI, 1997, pp. $147-154$.

13. ROARK J. R. Formulas for Stress and Strain. McGraw-Hill, New York, 2003.

\section{What do you think?}

To comment on this paper, please email up to 500 words to the editor at journals@ice.org.uk

Proceedings journals rely entirely on contributions sent in by civil engineers and related professionals, academics and students. Papers should be 2000-5000 words long, with adequate illustrations and references. Please visit www.thomastelford.com/journals for author guidelines and further details. 